\title{
Chemical Constituents from Roots of Sophora davidii (Franch.) Skeels and Their Glucose Transporter 4 Translocation Activities
}

\author{
Kangdi Li ${ }^{1,+}$, Yuanren Ma ${ }^{1,+}$, Tongxi Zhou ${ }^{1}$, Xinzhou Yang ${ }^{1, *}$ and Ho-Young Choi ${ }^{2, *(D)}$ \\ 1 School of Pharmaceutical Sciences, South-Central University for Nationalities, Wuhan 430074, China; \\ kdli@whu.edu.cn (K.L.); 13007136998@163.com (Y.M.); tc13627123095@163.com (T.Z.) \\ 2 College of Korean Medicine, Kyung Hee University, Seoul 02447, Korea \\ * Correspondence: xzyang@mail.scuec.edu.cn (X.Y.); hychoi@khu.ac.kr (H.-Y.C.); Tel.: +86-27-6784-1196 (X.Y.); \\ +82-2-961-9372 (H.-Y.C.) \\ + These authors contributed equally to this work.
}

Citation: Li, K.; Ma, Y.; Zhou, T.; Yang, X.; Choi, H.-Y. Chemical Constituents from Roots of Sophora davidii (Franch.) Skeels and Their Glucose Transporter 4 Translocation Activities. Molecules 2021, 26, 756. https://doi.org/10.3390/

molecules 26030756

Academic Editor: Lars Porskjær Christensen

Received: 8 January 2021

Accepted: 28 January 2021

Published: 1 February 202

Publisher's Note: MDPI stays neutral with regard to jurisdictional claims in published maps and institutional affiliations.

Copyright: (c) 2021 by the authors. Licensee MDPI, Basel, Switzerland. This article is an open access article distributed under the terms and conditions of the Creative Commons Attribution (CC BY) license (https:// creativecommons.org/licenses/by/ $4.0 /)$.

\begin{abstract}
Sophora davidii (Franch.) Skeels is a multi-purpose traditional medicine that has long been used for the treatment of various diseases. To discover the potential bioactive composition of $S$. davidii, a chemical investigation was thus performed. In this research, two new stilbene oligomers, Davidiol E-F (1-2), one new 4-aryl-substituted isoflavan Davidinin A (3), and one new 2-arylbenzofuran dimer, Shandougenine C (4), as well as six known compounds (5-10) were obtained from the ethyl acetate fraction of Sophora davidii (Franch.) Skeels. The structures of new compounds were established by extensive 1D and 2D nuclear magnetic resonance (NMR) spectra with mass spectroscopy data. The absolute configuration of 1-3 was assigned by comparing its experimental and calculated electronic circular dichroism (ECD) spectra. Compounds 1-10 promoted glucose transporter 4 (GLUT-4) translocations by the range of 1.28-2.60 folds, respectively. Compound 9 showed the most potent glucose transporter 4 translocations with 1.60 fold enhancement. The result attained in this study indicated that the separation and characterization of these compounds plays an important role in the research and development of new anti-diabetic drugs and pharmaceutical industry.
\end{abstract}

Keywords: Sophora davidii (Franch.) Skeels; stilbene oligomers; isoflavan; arylbenzofuran; GLUT4; ECD

\section{Introduction}

Diabetes mellitus (DM) is a common chronic noninfectious disease, which can make the body experience continuous hyperglycemia and long-term metabolic disorder, and lead to the damage, dysfunction, and failure of the whole body's tissues and organs [1]. According to the International Diabetes Federation, 463 million people worldwide currently have diabetes. Further, this number is expected to increase to 592 million, implying that there will be around a 50\% increase in diabetes by 2035 [2]. DM is classified into type 1 diabetes mellitus (T1DM) and type 2 diabetes mellitus (T2DM), in which T2DM accounts for nearly $95 \%$ of individuals. As insulin resistance is a major characteristic of T2DM, improving insulin resistance is a primary strategy to improve metabolic control in subjects with type 2 diabetes [3]. Glucose transporter type 4 (GLUT-4) is predominantly expressed in muscle cells and adipocytes [4]. The insulin-stimulated glucose uptake is performed through the solute carrier family 2, facilitated glucose transporter type 4, which is rapidly translocated to the plasma membrane in response to the hormone [5]. Therefore, this protein has a potential role in preventive or therapeutic approaches for diabetes.

Natural products (NPs), including herbal formulas and its extracts, have been used to treat human diseases with the unique system of theories and therapies for thousands of years, which have also been increasingly applied to treat T2DM. Much evidence has indicated that herbal medicines and their active ingredients possess anti-diabetics properties with less toxicity and fewer adverse effects [6]. Sophora davidii (Franch.) Skeels (Fabaceae 
family) is a deciduous shrub or dunga-runga growing in valley scrub, hill slopes, and sandy places in valleys below $3400 \mathrm{~m}$. It is mainly distributed in Gansu, Guangxi, Guizhou, Hebei, Henan, Hubei, Hunan, Jiangsu, Shaanxi, Sichuan, Xizang, Yunnan, and Zhejiang provinces of China [7]. The roots of $S$. davidii have been traditionally used to clear heat, sooth a sore throat, cool the blood and reduce swelling, as well as treat hematochezia, cough and dysentery, etc. [8]. In the previous paper, we reported that the flavonoid-rich extract of S. davidii showed a good effect in promoting GLUT-4 translocation and improving glucose uptake in L6 cells [9]. Further, we isolated and determined five new compounds, davidones A-E, and one new isoflavonoid, cyclolicoisoflavones $\mathrm{A}_{3}$, along with seven known compounds, leachianone A, brosimacutin $\mathrm{C}$, crotalarin, gerontoisoflavone $\mathrm{A}$, griffonianone $\mathrm{H}$, acacetin, and pterostilbene from the roots of $S$. davidii with some GLUT-4 translocation activities [10]. As a continuation of our search for new bioactive natural chemical substances from $S$. $d a-$ vidii, we further performed purification of an EtOAc fraction of the traditional herb that led to two new stilbene oligomers, Davidiol E-F (1-2), one new 4-aryl-substituted isoflavan Davidinin A (3), and one new 2-arylbenzofuran dimer, Shandougenine C (4), together with six known compounds (Figure 1). In this paper, we described the isolation and structural elucidation of the four new compounds as well as the GLUT- 4 translocation activities of compounds 1-10.

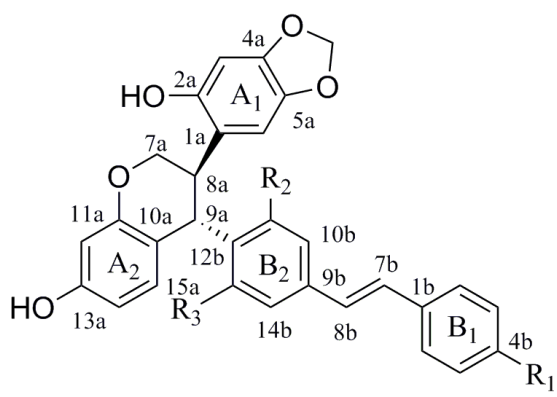

$1 \mathrm{R}_{1}=\mathrm{OH} \mathrm{R} \mathrm{R}_{2}=\mathrm{R}_{3}=\mathrm{OCH}_{3}$ $2 \mathrm{R}_{1}=\mathrm{H} \mathrm{R}_{2}=\mathrm{R}_{3}=\mathrm{OH}$<smiles>COc1cc([C@H]2OC[C@@H]3[C@@H]4CO[C@@H](c5cc(OC)c(O)c(OC)c5)[C@@H]4[C@H]23)cc(OC)c1O</smiles>

6<smiles>COc1ccc([Al]2c3ccc(O)cc3OCC2c2cc(O)cc3c2OCO3)c(O)c1</smiles>

3<smiles>Oc1ccc(-c2oc3cc4c(cc3c2-c2cc(-c3cc5cc6c(cc5o3)OCO6)c(O)cc2O)OCO4)c(O)c1</smiles>

7

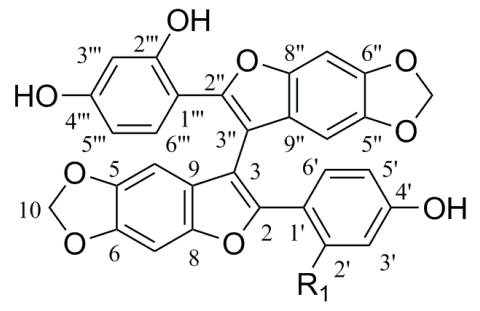

$4 \mathrm{R}_{1}=\mathrm{OCH}_{3}$

$5 \mathrm{R}_{1}=\mathrm{OH}$<smiles>O=c1c(-c2ccc(O)c(O)c2)coc2cc(O)cc(O)c12</smiles>

9<smiles>O=c1c(-c2ccc(O)cc2O)coc2cc(O)cc(O)c12</smiles>

Figure 1. The structures of compounds 1-10.

\section{Results and Discussion}

The IR spectrum of showed Davidiol E (1) the presence of hydroxyl $\left(3327 \mathrm{~cm}^{-1}\right)$ and aromatic $\left(1647 \mathrm{~cm}^{-1}\right.$ and $\left.1450 \mathrm{~cm}^{-1}\right)$ structures. The UV spectrum showed $\lambda_{\max }(\mathrm{MeOH})$ $(\log \varepsilon)$ at $230(3.40)$ and $310(3.84) \mathrm{nm}$ [11]. The ${ }^{1} \mathrm{H}$ NMR spectrum (Table 1) showed the presence of two para-coupled aromatic proton moieties on ring $\mathrm{A}_{1}$ at $\delta_{\mathrm{H}} 6.76(1 \mathrm{H}, \mathrm{s}$, $\mathrm{H}-6 \mathrm{a}), \delta_{\mathrm{H}} 6.30(1 \mathrm{H}, \mathrm{s}, \mathrm{H}-3 \mathrm{a})$, and an $\mathrm{ABX}$ spin system at $\delta_{\mathrm{H}} 6.28(1 \mathrm{H}, \mathrm{d}, J=8.3 \mathrm{~Hz}, \mathrm{H}-15 \mathrm{a})$, $\delta_{\mathrm{H}} 6.17(1 \mathrm{H}, \mathrm{d}, J=1.7 \mathrm{~Hz}, \mathrm{H}-12 \mathrm{a})$, and $\delta_{\mathrm{H}} 6.11(1 \mathrm{H}, \mathrm{dd}, J=8.3,1.7 \mathrm{~Hz}, \mathrm{H}-14 \mathrm{a})$ for ring $\mathrm{A}_{2}$, 
and two groups of meta-coupled aromatic protons belonging to rings $\mathrm{B}_{2}$ at $\delta_{\mathrm{H}} 6.79(1 \mathrm{H}$, br s, $\mathrm{H}-10 \mathrm{~b}), \delta_{\mathrm{H}} 6.70(1 \mathrm{H}, \mathrm{br} \mathrm{s}, \mathrm{H}-14 \mathrm{~b})$, and 4-hydroxyphenyl group (ring $\left.\mathrm{B}_{1}\right)$ at $\delta_{\mathrm{H}} 7.38(2 \mathrm{H}$, $\mathrm{d}, J=8.4 \mathrm{~Hz}, \mathrm{H}-2 \mathrm{~b} / 6 \mathrm{~b}), \delta_{\mathrm{H}} 6.75(2 \mathrm{H}, \mathrm{d}, J=8.4 \mathrm{~Hz}, \mathrm{H}-3 \mathrm{~b} / 5 \mathrm{~b})$. The ${ }^{1} \mathrm{H}$ NMR spectrum also displayed the presence of a trans-1,2-disubstituted vinyl group at $\delta_{\mathrm{H}} 7.12(1 \mathrm{H}, \mathrm{d}$, $J=16.3 \mathrm{~Hz}, \mathrm{H}-7 \mathrm{~b}), \delta_{\mathrm{H}} 6.91(1 \mathrm{H}, \mathrm{d}, J=16.3 \mathrm{~Hz}, \mathrm{H}-8 \mathrm{~b})$, and a methylenedioxy moiety with two non-equivalent protons at $\delta_{\mathrm{H}} 5.82\left(1 \mathrm{H}, \mathrm{s},-\mathrm{OCH}_{2} \mathrm{O}-\right)$ and $\delta_{\mathrm{H}} 5.78\left(1 \mathrm{H}, \mathrm{s},-\mathrm{OCH}_{2} \mathrm{O}-\right)$. The $\mathrm{HMBC}$ correlations of this $-\mathrm{OCH}_{2} \mathrm{O}-$ group $\left(\delta_{\mathrm{H}} 5.82, \delta_{\mathrm{H}} 5.78\right)$ with $\mathrm{C}-4 \mathrm{a}\left(\delta_{\mathrm{C}} 145.4\right)$ and $\mathrm{C}-5 \mathrm{a}$ $\left(\delta_{\mathrm{C}} 139.6\right)$ indicated that the oxygen atoms were linked to carbons $\mathrm{C}-4 \mathrm{a}$ and $\mathrm{C}-5 \mathrm{a}$ in the tetrasubstituted aromatic ring $\mathrm{A}_{1}$. The ${ }^{13} \mathrm{C}$ NMR spectrum of 1 revealed the presence of two methoxy groups at $\delta_{C} 56.2$ and 55.8, four aliphatic carbons at $\delta_{C} 100.3,70.6,34.7$, and 34.4 , besides 26 aromatic and olefinic carbons between $\delta_{C} 97.3$ and 158.9, and all protonated carbons were assigned from the HMQC spectrum. In the HMBC spectrum (Figure 2), the long-range correlations of $\mathrm{H}-7 \mathrm{~b}$ with $\mathrm{C}-2 \mathrm{~b}, \mathrm{C}-6 \mathrm{~b}\left(\delta_{\mathrm{C}} 127.8\right)$, and $\mathrm{C}-9 \mathrm{~b}\left(\delta_{\mathrm{C}} 137.3\right)$ and $\mathrm{H}-8 \mathrm{~b}$ with $\mathrm{C}-1 \mathrm{~b}\left(\delta_{\mathrm{C}} 128.2\right), \mathrm{C}-10 \mathrm{~b}\left(\delta_{\mathrm{C}} 102.3\right)$, and $\mathrm{C}-14 \mathrm{~b}\left(\delta_{\mathrm{C}} 104.0\right)$ indicated that the trans-1,2disubstituted vinyl group was attached to $\mathrm{B}_{1}$ and $\mathrm{B}_{2}$ rings. The correlations from $\mathrm{H}-7 \mathrm{a}$ to C-9a $\left(\delta_{C} 34.7\right)$ and C-11a $\left(\delta_{C} 154.5\right)$, from H-9a to C-10a $\left(\delta_{C} 117.6\right), C-11$ a $\left(\delta_{C} 154.5\right), C-14 a$ $\left(\delta_{\mathrm{C}} 107.7\right)$, and $\mathrm{C}-15 \mathrm{a}\left(\delta_{\mathrm{C}} 128.0\right)$, and the connections of $\mathrm{H}-7 \mathrm{a} / \mathrm{H}-8 \mathrm{a} / \mathrm{H}-9 \mathrm{a}$ were determined from the $\mathrm{H}^{1}-\mathrm{H}^{1} \mathrm{COSY}$, indicating that the $\mathrm{H}-7 \mathrm{a}, \mathrm{H}-8 \mathrm{a}$, and $\mathrm{H}-9 \mathrm{a}$ aliphatic protons could be assigned to the protons of the tetrahydrobenzopyran ring. The tetrahydrobenzopyran ring attached to $A_{1}$ ring and $B_{2}$ ring were also confirmed by the correlations between $\mathrm{H}-7 \mathrm{a}$ with C-1a $\left(\delta_{C} 117.8\right)$ and between $\mathrm{H}-8$ a with C-1a $\left(\delta_{C} 117.8\right), \mathrm{C}-2 \mathrm{a}\left(\delta_{\mathrm{C}} 150.0\right)$, and C-6a $\left(\delta_{\mathrm{C}}\right.$ 107.3) and between $\mathrm{H}-9 \mathrm{a}$ with $\mathrm{C}-10 \mathrm{~b}\left(\delta_{\mathrm{C}} 102.3\right), \mathrm{C}-11 \mathrm{~b}\left(\delta_{\mathrm{C}} 158.9\right)$. The relative configuration of $\mathrm{H}-8 \mathrm{a}$ and $\mathrm{H}-9 \mathrm{a}$ was inferred by the observed large coupling constants $(J=11.4 \mathrm{~Hz})$ for them and confirmed by correlations between $\mathrm{H}-8 \mathrm{a}$ with $\mathrm{H}-10 \mathrm{~b}$, and between $\mathrm{H}-9 \mathrm{a}$ with $\mathrm{H}-3 \mathrm{a}$ and $\mathrm{H}-6 \mathrm{a}$ in the ROESY spectrum. On the basis of these observations, $\mathrm{H}-8 \mathrm{a}$ and H-9a were in the opposite orientation [12]. As for the absolute configuration of 1, electronic circular dichroism (ECD) calculations of the enantiomers 8aR, 9aS-1, and 8aS, 9aR-1 were carried out using B3LYP/6-31G(d) optimized geometries at the B3LYP/6-311+G(d,p) level in $\mathrm{MeOH}$. The experimental and calculated ECD spectra of $\mathbf{1}$ were in good agreement. The calculated ECD spectrum for 1 showed the positive Cotton effect at $281 \mathrm{~nm}$ and the negative Cotton effect around $320 \mathrm{~nm}$ in the ECD spectrum (Figure 3). Therefore, Davidiol E was determined to be (8aR,9aS)-8a,9a-trans-2a,13a-dihydroxy-4a,5a-methylenedioxy-9a[(E)-6-(3,5-dimethoxyphenyl)-5-(4'-hydroxyphenyl)-ethenyl]-isoflavan.
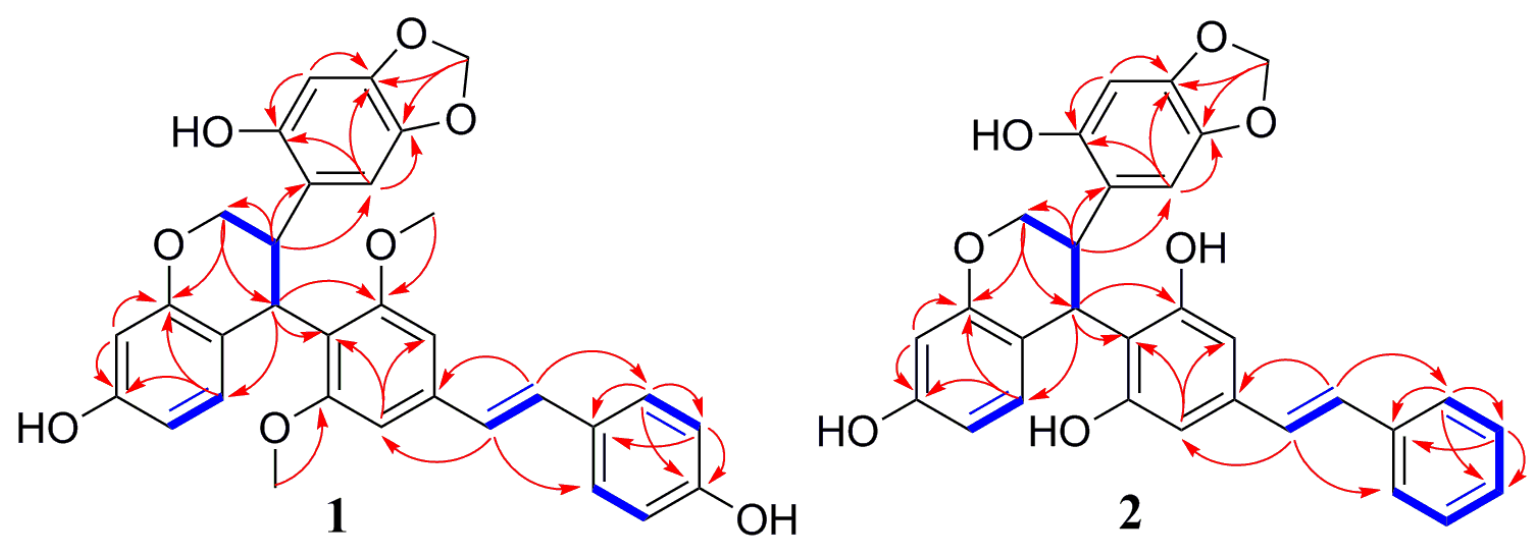

Figure 2. Key ${ }^{1} \mathrm{H}-{ }^{1} \mathrm{H}$ COSY $(-)$ and $\operatorname{HMBC}(\rightarrow)$ correlations of $\mathbf{1}$ and 2. 
Table 1. ${ }^{1} \mathrm{H}$ and ${ }^{13} \mathrm{C}$ NMR data of compounds $\mathbf{1}$ and $\mathbf{2}\left(\delta_{\mathrm{H}}\right.$ in ppm, $J$ in $\left.\mathrm{Hz}\right)$.

\begin{tabular}{|c|c|c|c|c|}
\hline \multirow{2}{*}{ No. } & \multicolumn{2}{|c|}{1} & \multicolumn{2}{|c|}{2} \\
\hline & $\delta \mathrm{c}$ & $\delta_{\mathrm{H}}$ Mult. $(J$ in $\mathrm{Hz})$ & $\delta \mathrm{c}$ & $\delta_{\mathrm{H}}$ Mult. $(J$ in $\mathrm{Hz})$ \\
\hline $1 \mathrm{a}$ & 117.8 & & 118.2 & \\
\hline $2 a$ & 150.0 & & 150.1 & \\
\hline $3 a$ & 97.3 & $6.30, \mathrm{~s}$ & 97.3 & $6.35, \mathrm{~s}$ \\
\hline $4 a$ & 145.4 & & 145.4 & \\
\hline $5 a$ & 139.6 & & 139.5 & \\
\hline $6 a$ & 107.3 & $6.76, \mathrm{~s}$ & 107.4 & $6.93, \mathrm{~s}$ \\
\hline \multirow[t]{2}{*}{$7 \mathrm{a}$} & 70.6 & 4.10, dd $(10.3,3.2)$ & 70.7 & $4.15, \mathrm{dd}(10.2,3.5)$ \\
\hline & & $3.85, \mathrm{t}(10.7)$ & 34.0 & $3.72, \mathrm{t}(10.7)$ \\
\hline $8 a$ & 34.4 & $4.32, \mathrm{td}(11.3,2.7)$ & 34.2 & $4.49, \operatorname{td}(11.4,3.5)$ \\
\hline $9 a$ & 34.7 & $4.89, \mathrm{~d}(11.6)$ & 117.7 & $4.82, \mathrm{~d}(11.7)$ \\
\hline $10 \mathrm{a}$ & 117.6 & & 154.7 & \\
\hline $11 a$ & 154.5 & & 102.2 & \\
\hline $12 \mathrm{a}$ & 102.3 & $6.17, \mathrm{~d}(1.7)$ & 155.8 & $6.15, \mathrm{~d}(2.4)$ \\
\hline $13 a$ & 155.8 & & 107.7 & \\
\hline $14 a$ & 107.7 & $6.11, \mathrm{dd}(8.3,1.7)$ & 128.4 & $6.13, \mathrm{dd}(8.3,2.4)$ \\
\hline $15 a$ & 128.0 & $6.28, \mathrm{~d}(8.3)$ & 137.1 & $6.38, \mathrm{~d}(8.3)$ \\
\hline $1 b$ & 128.2 & & 126.4 & \\
\hline $2 b$ & 127.8 & $7.38, \mathrm{~d}(8.4)$ & 128.7 & $7.55, \mathrm{~d}(7.4)$ \\
\hline $3 b$ & 115.6 & $6.75, \mathrm{~d}(8.4)$ & 128.4 & $7.34, \mathrm{t}(7.8)$ \\
\hline $4 b$ & 157.3 & & 128.7 & $7.24, \mathrm{t}(7.4)$ \\
\hline $5 b$ & 115.6 & $6.75, \mathrm{~d}(8.4)$ & 126.4 & $7.34, \mathrm{t}(7.8)$ \\
\hline $6 b$ & 127.8 & $7.38, \mathrm{~d}(8.4)$ & 127.2 & $7.55, \mathrm{~d}(7.4)$ \\
\hline $7 \mathrm{~b}$ & 128.4 & $7.12, \mathrm{~d}(16.3)$ & 128.9 & 6.86, d (16.3) \\
\hline $8 b$ & 125.4 & 6.91, d (16.3) & 135.7 & $6.98, \mathrm{~d}(16.3)$ \\
\hline $9 b$ & 137.3 & & 105.6 & \\
\hline $10 \mathrm{~b}$ & 102.3 & $6.79, \mathrm{~s}$ & 157.2 & $6.31, \mathrm{~s}$ \\
\hline $11 b$ & 158.9 & & 115.4 & \\
\hline $12 b$ & 117.9 & & 156.9 & \\
\hline $13 b$ & 158.9 & & 104.2 & \\
\hline $14 \mathrm{~b}$ & 104.0 & $6.70, \mathrm{~s}$ & 100.3 & $6.50, \mathrm{~s}$ \\
\hline \multirow[t]{2}{*}{$-\mathrm{OCH}_{2} \mathrm{O}-$} & 100.3 & $5.82, \mathrm{~s}$ & 118.2 & $5.82, \mathrm{~d}(0.7)$ \\
\hline & & $5.78, \mathrm{~s}$ & & $5.80, \mathrm{~d}(0.7)$ \\
\hline $2 \mathrm{a}-\mathrm{OH}$ & & $9.06, \mathrm{~s}$ & & $9.11, \mathrm{~s}$ \\
\hline $13 \mathrm{a}-\mathrm{OH}$ & & $9.05, \mathrm{~s}$ & & 9.01 \\
\hline $4 b-\mathrm{OH}$ & & $9.59, \mathrm{~s}$ & & \\
\hline $11 b-\mathrm{OH}$ & & & & $8.95, \mathrm{~s}$ \\
\hline $13 b-\mathrm{OH}$ & & & & $9.52, \mathrm{~s}$ \\
\hline 11b-OMe & 56.2 & $3.80, \mathrm{~s}$ & & \\
\hline $13 b-O M e$ & 55.8 & $3.49, \mathrm{~s}$ & & \\
\hline
\end{tabular}

${ }^{1} \mathrm{H}$ NMR and ${ }^{13} \mathrm{C}$ NMR were measured at $600 \mathrm{MHz}$ and $150 \mathrm{MHz}$ in DMSO- $d_{6}$.

The ${ }^{1} \mathrm{H}$ and ${ }^{13} \mathrm{C}-\mathrm{NMR}$ spectra data of Davidiol F (2) (Table 1) were very similar to those of 1, except for a monosubstituted phenyl group at $\delta_{\mathrm{H}} 7.55(2 \mathrm{H}, \mathrm{d}, J=7.4 \mathrm{~Hz}, \mathrm{H}-$ $2 \mathrm{~b} / 6 \mathrm{~b}), \delta_{\mathrm{H}} 7.34(2 \mathrm{H}, \mathrm{t}, J=7.8 \mathrm{~Hz}, \mathrm{H}-3 \mathrm{~b} / 5 \mathrm{~b})$, and $\delta_{\mathrm{H}} 7.24(1 \mathrm{H}, \mathrm{t}, J=7.6 \mathrm{~Hz}, \mathrm{H}-4 \mathrm{~b})$ for ring $B_{2}$. Meanwhile, the absence of two methoxy carbons at C-11b-OMe and C-13b-OMe was observed in the ${ }^{13} \mathrm{C}$ NMR spectrum. Compound 2 had the same stereochemistry as 1, which was substantiated by the similar ROESY spectrum and the large coupling constant of $\mathrm{H}-8 \mathrm{a} / \mathrm{H}-9 \mathrm{a}(J=11.7 \mathrm{~Hz})$. In a similar manner to 1 , the absolute configuration of 2 was established as $8 \mathrm{aR}, 9 \mathrm{aS}$ by the positive Cotton effect at $284 \mathrm{~nm}$ and the negative Cotton effect around $314 \mathrm{~nm}$ in the ECD spectrum (Figure 3). Therefore, Davidiol F was determined to be $(8 \mathrm{a} R, 9 \mathrm{a} S)-8 \mathrm{a}, 9 \mathrm{a}-$ trans-2a,13a-dihydroxy-4a,5a-methylenedioxy-9a-[(E)-6(3,5-dihydroxyphenyl)-5-phenyl-ethenyl]-isoflavan. 


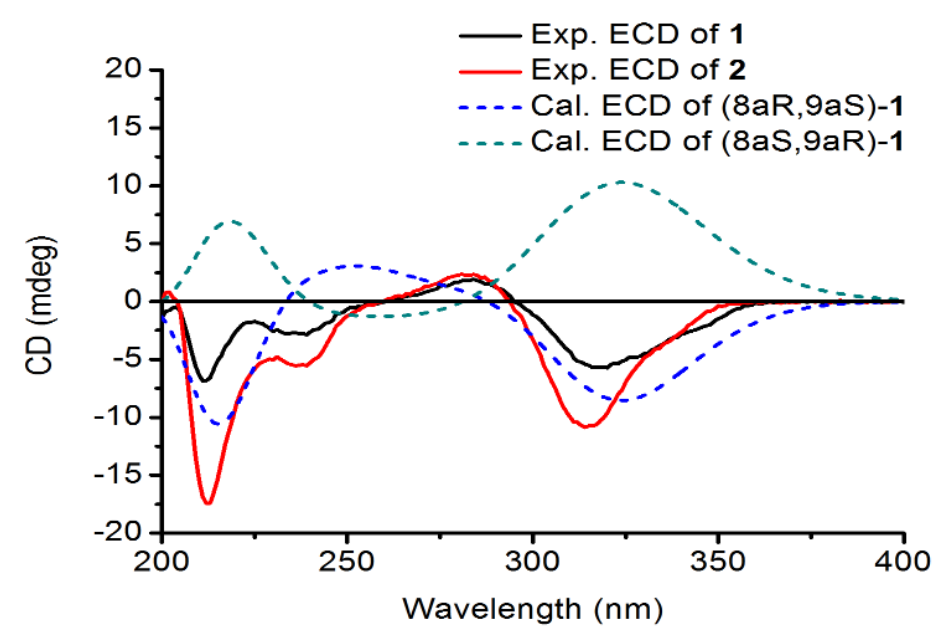

Figure 3. Experimental and calculated electronic circular dichroism (ECD) spectra of compounds 1 and 2.

The IR absorptions of Davidinin A (3) suggested the presence of hydroxyl group $\left(3370 \mathrm{~cm}^{-1}\right)$, aromatic $\left(1655\right.$ and $\left.1452 \mathrm{~cm}^{-1}\right)$, and methylenedioxy $\left(-\mathrm{OCH}_{2} \mathrm{O}-\right)(1115$ and $1032 \mathrm{~cm}^{-1}$ ) group. The ${ }^{1} \mathrm{H}$ NMR data of 3 (Table 2) established characteristic resonances for two 1,2,4-trisubstituted benzene rings [ $\delta_{\mathrm{H}} 6.67\left(1 \mathrm{H}, \mathrm{d}, J=8.5 \mathrm{~Hz}, \mathrm{H}-6^{\prime \prime}\right), \delta_{\mathrm{H}} 6.36(1 \mathrm{H}, \mathrm{d}$, $\left.J=2.2 \mathrm{~Hz}, \mathrm{H}-3^{\prime \prime}\right)$, and $\delta_{\mathrm{H}} 6.29\left(1 \mathrm{H}, \mathrm{dd}, J=8.5,2.2 \mathrm{~Hz}, \mathrm{H}-5^{\prime \prime}\right)$; and $\delta_{\mathrm{H}} 6.54(1 \mathrm{H}, \mathrm{d}, J=8.0 \mathrm{~Hz}$, $\mathrm{H}-5), \delta_{\mathrm{H}} 6.26(1 \mathrm{H}, \mathrm{br} \mathrm{s}, \mathrm{H}-8)$, and $\delta_{\mathrm{H}} 6.25(1 \mathrm{H}$, overlapped, $\left.\mathrm{H}-6)\right]$, and a pair of isolated singlet signals at $\delta_{\mathrm{H}} 6.72\left(1 \mathrm{H}, \mathrm{s}, \mathrm{H}-6^{\prime}\right)$ and $6.32\left(1 \mathrm{H}, \mathrm{s}, \mathrm{H}-3^{\prime}\right)$. A methylenedioxy group signal at $\delta_{\mathrm{H}} 5.76,5.75$ (each $1 \mathrm{H}$, br s, $\left.\mathrm{H}-7^{\prime \prime}\right)$, a methoxyl group at $\delta_{\mathrm{H}} 3.70\left(3 \mathrm{H}, \mathrm{s}, 4^{\prime \prime}-\mathrm{OMe}\right)$, and four aliphatic protons at $\delta_{\mathrm{H}} 4.51(1 \mathrm{H}, \mathrm{d}, J=7.3 \mathrm{~Hz}, \mathrm{H}-4), \delta_{\mathrm{H}} 4.20(1 \mathrm{H}, \mathrm{dd}, J=10.6 \mathrm{~Hz}, 3.1 \mathrm{~Hz}$, $\mathrm{H}-2), \delta_{\mathrm{H}} 4.08(1 \mathrm{H}, \mathrm{dd}, J=10.6 \mathrm{~Hz}, 7.1 \mathrm{~Hz}, \mathrm{H}-2)$, and $\delta_{\mathrm{H}} 3.60(1 \mathrm{H}, \mathrm{m}, \mathrm{H}-3)$ were observed in the ${ }^{1} \mathrm{H}$ NMR spectrum. The ${ }^{13} \mathrm{C}$ NMR, DEPT (Table 2) and the HSQC spectra showed 23 carbon signals, including eighteen aromatic carbons, a methylenedioxy carbon at $\delta_{\mathrm{C}} 101.9$ $\left(\mathrm{C}-7^{\prime}\right)$, an oxymethylene carbon at $\delta_{\mathrm{C}} 69.1(\mathrm{C}-2)$, a methoxyl carbon at $\delta_{\mathrm{C}} 55.5\left(4^{\prime \prime}-\mathrm{OMe}\right)$, and two methines at $\delta_{\mathrm{C}} 39.2(\mathrm{C}-4)$ and $\delta_{\mathrm{C}} 38.9(\mathrm{C}-3)$. The presence of a benzotetrahydropyran ring was supported by HMBC correlations (Figure 4) from $\mathrm{H}-2$ to $\mathrm{C}-8$ and $\mathrm{C}-4$, and from $\mathrm{H}-4$ to $\mathrm{C}-5$, C-9 and $\mathrm{C}-10$, along with the linkage moiety $\mathrm{CH}_{2}(2)-\mathrm{CH}(3)-\mathrm{CH}(4)$ from the ${ }^{1} \mathrm{H}-{ }^{1} \mathrm{H}$ COSY correlations of $\mathrm{H}-2 / \mathrm{H}-3 / \mathrm{H}-4$. Moreover, the HMBC correlations from a methylenedioxy proton $\left(\delta_{\mathrm{H}} 5.76,5.75\right)$ with $\mathrm{C}-4^{\prime}\left(\delta_{\mathrm{C}} 147.6\right)$ and $\mathrm{C}-5^{\prime}\left(\delta_{\mathrm{C}} 142.0\right)$ suggested that the methylenedioxy group was located at $\mathrm{C}-5^{\prime}, \mathrm{C}-6^{\prime}$. The location of ring $\mathrm{B}$ and ring $\mathrm{C}$ were assigned at $\mathrm{C}-3$ and $\mathrm{C}-4$ by the key HMBC correlations from $\mathrm{H}-3$ to $\mathrm{C}-\mathrm{1}^{\prime}$ and $\mathrm{C}-2^{\prime}$, and from $\mathrm{H}-4$ to $\mathrm{C}-1^{\prime}, \mathrm{C}-2^{\prime}$, and C- $6^{\prime}$. Regarding the relative configuration of 3, ROESY cross peaks between $\mathrm{H}-3 / \mathrm{H}-6^{\prime \prime}$ and $\mathrm{H}-4 / \mathrm{H}-6^{\prime}$ suggested that $\mathrm{H}-3$ and $\mathrm{H}-4$ were in the opposite orientation. Finally, the absolute configuration of 3 was determined as $3 R, 4 R$ by comparison of theoretical and experimental ECD spectra (Figure 5). Its ECD spectrum displayed a negative Cotton effect at $240 \mathrm{~nm}$ and a positive Cotton effect in the range $260-280 \mathrm{~nm}$, which was in agreement with those of Manuifolin Q [13], an analogue whose stereochemistry as $(3 R, 4 R)$ has been unambiguously elucidated. Thus, Davidinin A was determined to be (3R,4R)-3,4-trans-7, $2^{\prime}$-dihydroxy-4', $5^{\prime}$-methylenedioxy-4-(4-methoxy-2hydroxyphenyl)-isoflavan. 
Table 2. ${ }^{1} \mathrm{H}$ and ${ }^{13} \mathrm{C}$ NMR data of compounds 3 and $4\left(\delta_{\mathrm{H}}\right.$ in ppm, $J$ in $\left.\mathrm{Hz}\right)$.

\begin{tabular}{|c|c|c|c|c|}
\hline \multirow{2}{*}{ No. } & \multicolumn{2}{|c|}{3} & \multicolumn{2}{|c|}{4} \\
\hline & $\delta \mathrm{c}$ & $\delta_{\mathrm{H}}$ Mult. $(J$ in $\mathrm{Hz})$ & $\delta \mathrm{c}$ & $\delta_{\mathrm{H}}$ Mult. $(J$ in $\mathrm{Hz})$ \\
\hline \multirow[t]{2}{*}{2} & 69.1 & $4.20, \mathrm{dd},(10.6,3.1)$ & 151.8 & \\
\hline & & $4.08, \mathrm{dd},(10.6,7.1)$ & & \\
\hline 3 & 38.9 & $3.60, \mathrm{~m}$ & 111.2 & \\
\hline 4 & 39.2 & $4.51, \mathrm{~d},(7.3)$ & 99.5 & $6.72, \mathrm{~s}$ \\
\hline 5 & 132.1 & $6.54, \mathrm{~d},(8.0)$ & 145.5 & \\
\hline 6 & 109.4 & 6.25 , overlapped & 147.2 & \\
\hline 7 & 157.7 & & 94.0 & $7.01, \mathrm{~s}$ \\
\hline 8 & 103.4 & 6.26 , br s & 150.9 & \\
\hline 9 & 156.8 & & 123.5 & \\
\hline 10 & 117.7 & & 102.5 & 5.88 , overlapped \\
\hline $1^{\prime}$ & 120.4 & & 113.4 & \\
\hline $2^{\prime}$ & 150.8 & & 159.4 & \\
\hline $3^{\prime}$ & 98.3 & $6.32, \mathrm{~s}$ & 100.2 & $6.31, \mathrm{~d},(2.2)$ \\
\hline $4^{\prime}$ & 147.6 & & 161.0 & \\
\hline $5^{\prime}$ & 142.0 & & 108.7 & $6.42, \mathrm{dd},(8.4,2.2)$ \\
\hline $6^{\prime}$ & 108.6 & $6.72, \mathrm{~s}$ & 132.0 & $7.36, \mathrm{~d},(8.4)$ \\
\hline \multirow[t]{2}{*}{$7^{\prime}$} & 101.9 & 5.76, br s & & \\
\hline & & 5.75 , br s & & \\
\hline $1^{\prime \prime}$ & 124.8 & & & \\
\hline $2^{\prime \prime}$ & 157.0 & & 151.3 & \\
\hline $3^{\prime \prime}$ & 102.1 & $6.36, \mathrm{~d},(2.2)$ & 110.4 & \\
\hline $4^{\prime \prime}$ & 160.5 & & 99.8 & $6.38, \mathrm{~s}$ \\
\hline $5^{\prime \prime}$ & 105.9 & $6.29, \mathrm{dd},(8.5,2.2)$ & 145.5 & \\
\hline $6^{\prime \prime}$ & & $6.67, \mathrm{~d},(8.5)$ & 147.2 & \\
\hline $7^{\prime \prime}$ & & & 93.9 & $6.99, \mathrm{~s}$ \\
\hline $8^{\prime \prime}$ & & & 151.0 & \\
\hline $9^{\prime \prime}$ & & & 123.5 & \\
\hline $10^{\prime \prime}$ & & & 102.4 & 5.87 , overlapped \\
\hline $1^{\prime \prime \prime}$ & & & 111.3 & \\
\hline $2^{\prime \prime \prime}$ & & & 157.3 & \\
\hline $3^{\prime \prime \prime}$ & & & 103.8 & $6.26, \mathrm{~d},(2.4)$ \\
\hline $4^{\prime \prime \prime}$ & & & 160.6 & \\
\hline $5^{\prime \prime \prime}$ & & & 108.4 & $6.24, \mathrm{dd},(8.3,2.4)$ \\
\hline $6^{\prime \prime \prime}$ & & & 132.2 & $7.17, \mathrm{~d},(8.3)$ \\
\hline $2^{\prime}-\mathrm{OMe}$ & & & 55.3 & $3.33, \mathrm{~s}$ \\
\hline 4"-OMe & 55.5 & $3.70, \mathrm{~s}$ & & \\
\hline
\end{tabular}

${ }^{1} \mathrm{H}$ NMR and ${ }^{13} \mathrm{C}$ NMR were measured at $600 \mathrm{MHz}$ and $150 \mathrm{MHz}$ in $\mathrm{MeOH}-d_{4}$.
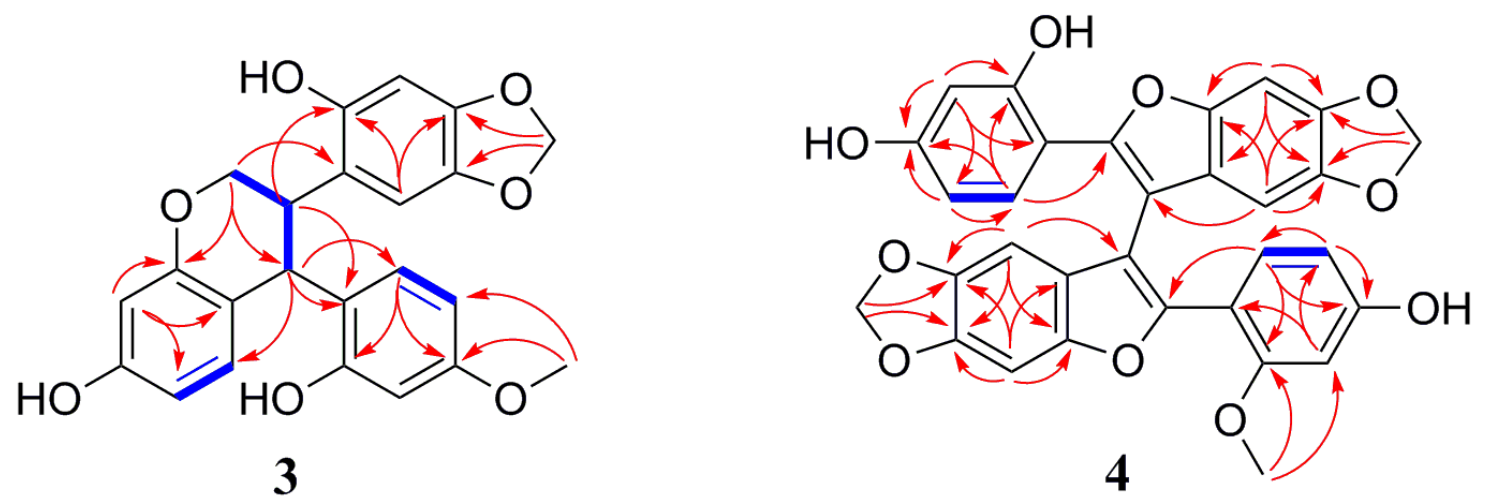

Figure 4. Key ${ }^{1} \mathrm{H}-{ }^{1} \mathrm{H}$ COSY $(-)$ and $\operatorname{HMBC}(\rightarrow)$ correlations of 3 and 4. 


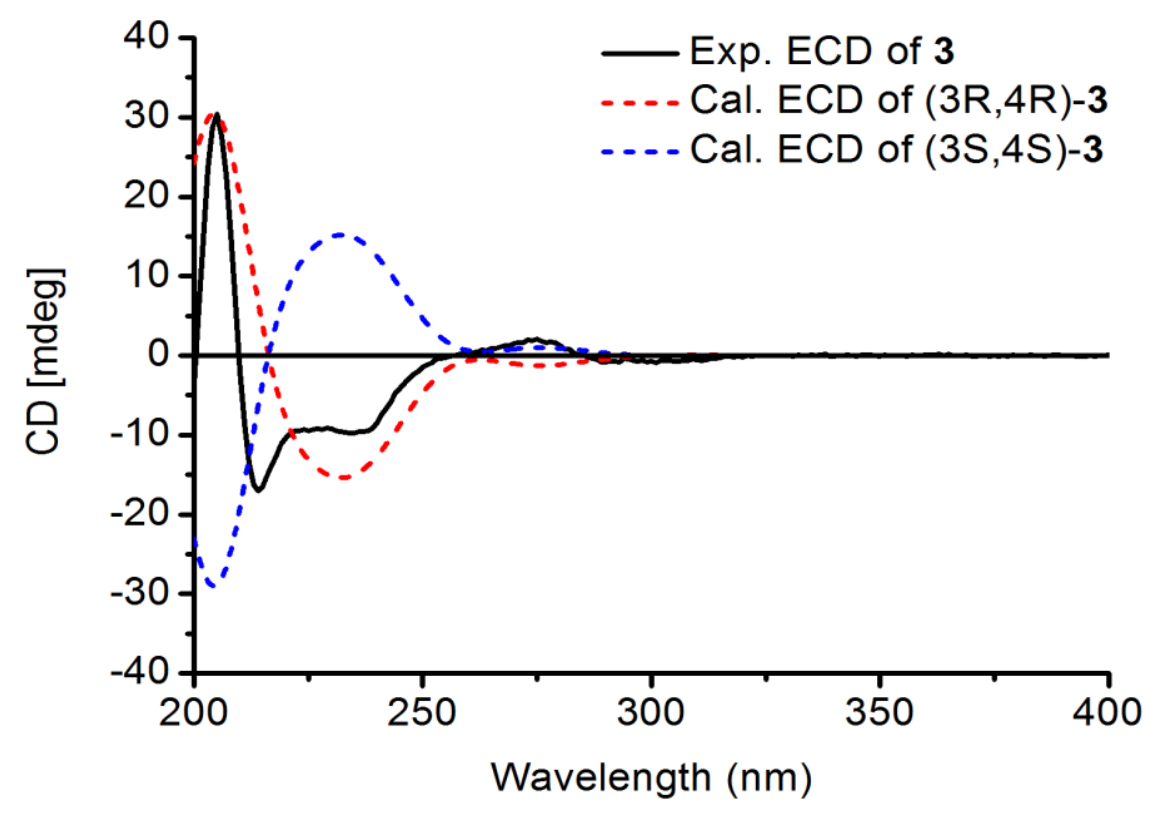

Figure 5. Experimental and calculated ECD spectra of compound 3.

The IR spectrum of shandougenine $C(4)$ was similar to that of 3 , also indicating that 4 had $\left(3343 \mathrm{~cm}^{-1}\right)$, aromatic $\left(1452 \mathrm{~cm}^{-1}\right)$, and methylenedioxy $\left(1032 \mathrm{~cm}^{-1}\right)$ groups. The ${ }^{1} \mathrm{H}$ NMR spectrum (Table 2) exhibited two sets of ABX system signals at $\delta_{\mathrm{H}} 7.36(1 \mathrm{H}, \mathrm{d}$, $\left.J=8.4 \mathrm{~Hz}, \mathrm{H}-6^{\prime}\right), \delta_{\mathrm{H}} 6.31\left(1 \mathrm{H}, \mathrm{d}, J=2.2 \mathrm{~Hz}, \mathrm{H}-3^{\prime}\right)$, and $\delta_{\mathrm{H}} 6.42(1 \mathrm{H}, \mathrm{dd}, J=8.4,2.2 \mathrm{~Hz}$, H-5 $\left.{ }^{\prime}\right)$; and at $\delta_{\mathrm{H}} 7.17\left(1 \mathrm{H}, \mathrm{d}, J=8.3 \mathrm{~Hz}, \mathrm{H}-6^{\prime \prime \prime}\right), \delta_{\mathrm{H}} 6.26\left(1 \mathrm{H}, \mathrm{d}, J=2.4 \mathrm{~Hz}, \mathrm{H}-3^{\prime \prime \prime}\right)$, and $\delta_{\mathrm{H}} 6.24\left(1 \mathrm{H}, \mathrm{dd}, J=8.3,2.4 \mathrm{~Hz}, \mathrm{H}-5^{\prime \prime \prime}\right)$; four singlet signals $\left[\delta_{\mathrm{H}} 7.01(1 \mathrm{H}, \mathrm{s}, \mathrm{H}-7), \delta_{\mathrm{H}} 6.99\right.$ $\left(1 \mathrm{H}, \mathrm{s}, \mathrm{H}-7^{\prime \prime}\right), \delta_{\mathrm{H}} 6.38\left(1 \mathrm{H}, \mathrm{s}, \mathrm{H}-4^{\prime \prime}\right)$, and $\left.\delta_{\mathrm{H}} 6.72(1 \mathrm{H}, \mathrm{s}, \mathrm{H}-4)\right]$, two methylenedioxy $\left[\delta_{\mathrm{H}}\right.$ $5.88,5.87$ (each $2 \mathrm{H}$, overlapped, $\left.\left.\mathrm{H}-10, \mathrm{H}-10^{\prime \prime}\right)\right]$, and a methoxyl group $\left[\delta_{\mathrm{H}} 3.33(3 \mathrm{H}, \mathrm{s}\right.$, $\left.\left.2^{\prime}-\mathrm{OMe}\right)\right]$ were shown in the ${ }^{1} \mathrm{H}$ NMR spectrum. Furthermore, two sets of similar carbon chemical shift values were found in the ${ }^{13} \mathrm{C}$ NMR spectrum, which suggested that 4 might be a dimer. These spectroscopic characteristics of compound 4 were similar to the known compound shandougenine B [14], a 2-arylbenzofuran dimer previously isolated from the roots of Sophora tonkinensis. The difference was that 2'-OH was substituted by a methoxy group in compound 4 . The correlation of $\mathrm{H}_{3}-2^{\prime}-\mathrm{OMe}$ to $\mathrm{C}-2^{\prime}\left(\delta_{\mathrm{C}} 159.4\right)$ and $\mathrm{C}-3^{\prime}\left(\delta_{\mathrm{C}} 100.2\right)$ suggested that $2^{\prime}-\mathrm{OMe}$ was linked to $\mathrm{C}-2^{\prime}$ according to the HMBC spectrum (Figure 4). Thus, shandougenine $C$ was determined to be 3,3"-bis[2-(2-methoxy-4-hydroxyphenyl)-2(2,4-dihydroxyphenyl)-5,6-methylenedioxybenzofuran].

The known compounds Shandougenine A (5) [14], (+)-Lirioresinol-A (6) [15], Shandougenine B (7) [14], 2-(2',4'-dihydroxyphenyl)-5,6-methylenedioxybenzofuran (8) [16], isoluteolin (9) [17], and 2', 4',5,7-tetrahydroxyisoflavone (10) [18] were identified by comparison of their spectroscopic data with those in the literature.

In order to test the potential GLUT-4 translocation activity of compounds 1-10, a L6 cell line which stably expressed Myc-GLUT4-mOrange was used to evaluate the effects. Insulin (100 nM) was used as the positive control. The compounds Davidiol E-F (1-2), Davidinin A (3), Shandougenine C (4), Shandougenine A (5), Shandougenine B (7), 2-(2', 4'dihydroxyphenyl)-5,6-methylenedioxybenzofuran (8) and 2',4',5,7-tetrahydroxyisoflavone (10) exerted weak activity, increasing GLUT-4 translocation by $0.41-0.92$ folds, respectively. (+)-Lirioresinol-A (6) possesses a moderate effect on promoting GLUT-4 translocation, which increased GLUT-4 translocation to 2.39 folds. Isoluteolin (9) was the most active compound, exhibiting good GLUT-4 translocation activity with 1.60-fold enhancement (Figure 6). Compared with 10, they all exhibited a set of ABX system signals on $\mathrm{B}$ ring; the only difference was the hydroxyl group connected to $3^{\prime}$ and $4^{\prime}$ of B ring in compound $\mathbf{9}$, which may enhance the activities of GLUT-4 translocation. The laser-scanning confocal microscope LSM 700 (Carl Zeiss, Jena, Germany) was used to detect the fluorescence to 
indirectly reflect the content of GLUT4 on the plasma membrane in L6 cells (Supplementary Materials S46). The greater intensity of the fluorescence reflects the greater content of GLUT4 on the plasma membrane. Confocal images in L6 cells incubated in the absence (basal) or presence of compound 9 for 30 min (L6 cells were infected with Myc-GLUT4mOrange in order to detect externalized GLUT-4 by confocal microscopy) (Figure 7).

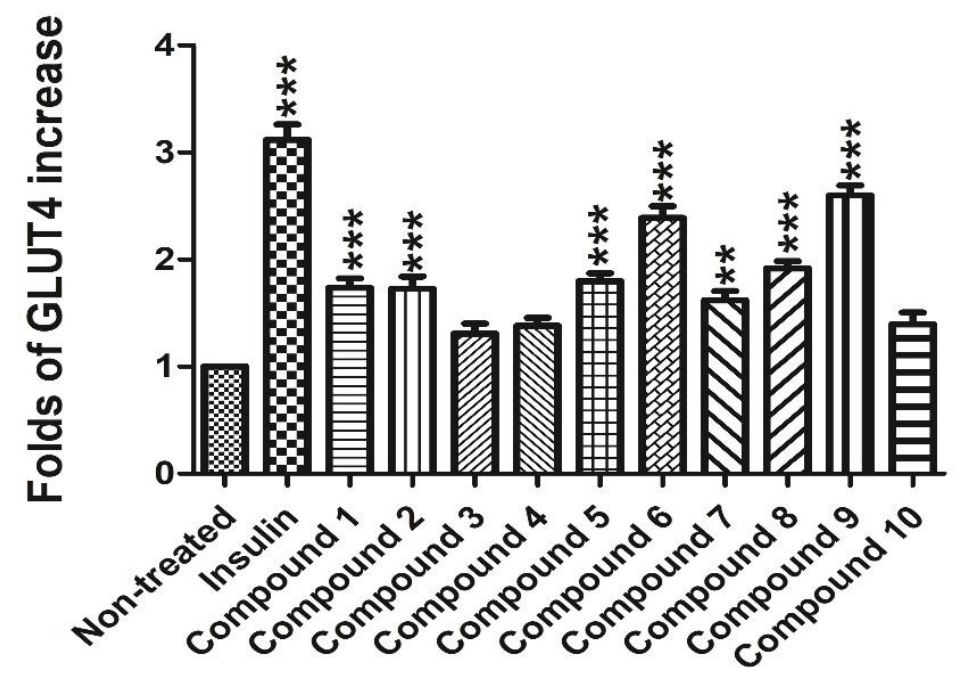

Figure 6. GLUT-4 translocation activities of compounds 1-10 ${ }^{* *} p<0.01$, compared with non-treated groups; $* * * p<0.001$, compared with non-treated group).

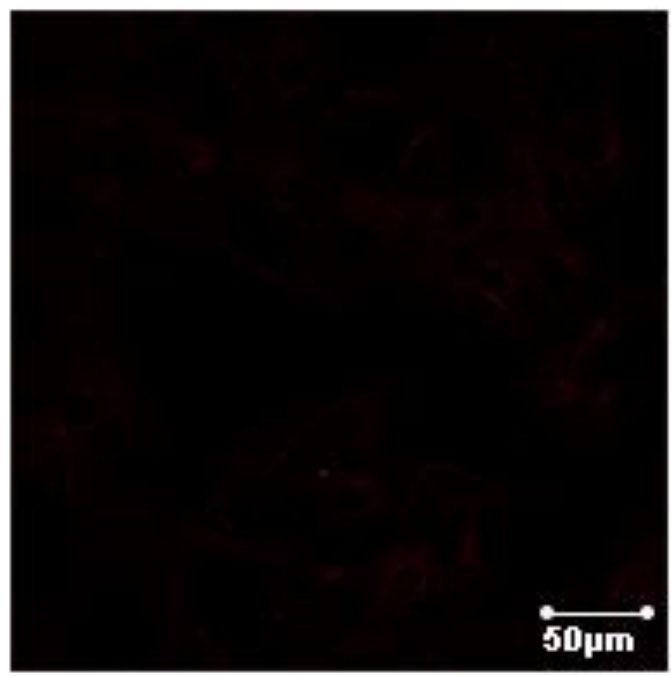

Omin

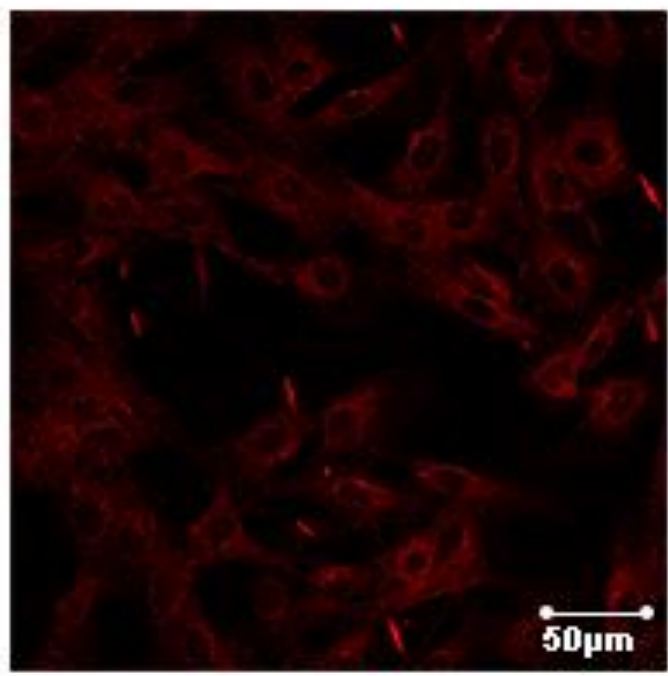

$30 \mathrm{~min}$

Figure 7. Effects of compound 9 on stimulating GLUT-4 translocation in L6 cells.

\section{Materials and Methods}

\subsection{General Information}

UV and IR spectra were determined on a Shimadzu UV-250 spectrometer (Shimadzu (China) Co., Ltd., Shanghai, China) and a Shimadzu FTIR-8400S spectrometer (Shimadzu (China) Co., Ltd., Shanghai, China), respectively. Optical rotations were measured using an Autopol IV-T automatic polarimeter (Rudolph Research Analytical, Hackettstown, NJ, USA). Circular dichroism (CD) spectra were recorded on a JASCO J-720 W spectrophotometer (JASCO China (Shanghai) Co., Ltd., Shanghai, China). The HRESIMS data were recorded on a UHPLC System and the Q Exactive HF Mass Spectrometer (Thermo Fisher Scientific, 
Waltham, MA, USA). A Thermo 70105-159070 Betasil C18 column $(5 \mu \mathrm{m}, 10 \mathrm{~mm} \times 150 \mathrm{~mm}$, Thermo Fisher Scientific, Waltham, MA, USA) was used for semipreparative HPLC. A Waters 2535 HPLC fitted with a 2998 Photodiode Array Detector and a 2707 Autosampler (Waters, Milford, MA, USA) was used for the semipreparative separations. All the solvents used for chromatography were of HPLC-grade and all the other chemicals were of analytical reagent grade. HPLC-grade acetonitrile was purchased from Merck Chemical Company (Darmstadt, Germany). Silica gel (300-400 mesh) was used for medium-pressure column chromatography and GF254 for TLC (Qingdao HaiYang Chemical Group Co., Qingdao, China). Sephadex LH-20 (Amersham Pharmacia Biotech Co., Piscataway, NJ, USA) was also used for column chromatography.

\subsection{Materials}

The roots of $S$. davidii (Franch.) Skeels (age 12-15 years) were collected from Xiuwen county, Guizhou province, China (at altitudes of 1200 to $1300 \mathrm{~m}$ ), in June 2014. The roots were dried at room temperature, macerated into a fine powder, and stored at room temperature. The identification was done by Professor Dingrong Wan of School of Pharmaceutical Sciences, South-Central University for Nationalities (SCUN), Wuhan, China. A voucher specimen (SC0801) is deposited in School of Pharmaceutical Sciences, SCUN, Wuhan, China.

\subsection{Extraction and Isolation}

Air-dried roots of Sophora davidii $(18 \mathrm{~kg}$ ) were triturated and then extracted with $80 \%$ $\mathrm{EtOH}(4 \times 20 \mathrm{~L}, 3$ days each $)$ at room temperature. The EtOH extract $(850 \mathrm{~g})$ was suspended in $\mathrm{H}_{2} \mathrm{O}(2.0 \mathrm{~L})$ and then partitioned successively with petroleum ether $(\mathrm{PE})(4 \times 10 \mathrm{~L})$, ethyl acetate $($ EtOAc) $(4 \times 10 \mathrm{~L})$, and n-butyl alcohol $(n-\mathrm{BuOH})(4 \times 10 \mathrm{~L})$ to give a PE extract $(90 \mathrm{~g})$, EtOAc extract $(215 \mathrm{~g})$, and $n$-BuOH extract $(110 \mathrm{~g})$, respectively. The EtOAc extraction (200 g) was separated into sixteen fractions (F1-F16) by silica-gel column chromatography (300-400 mesh) eluting with a gradient solvent system of $\mathrm{CH}_{2} \mathrm{Cl}_{2} / \mathrm{MeOH}(200: 1,100: 1,80: 1$, $60: 1,40: 1,20: 1,10: 1,5: 1,3: 1,0: 1, v / v)$. The fraction 5 (2.60 g) was subjected to a Sephadex LH-20 (eluted with MeOH) to afford six subfractions (F5-1 to F5-6). F5-2 was applied to semi-preparative $\mathrm{HPLC}\left(\mathrm{CNCH}_{3} / \mathrm{H}_{2} \mathrm{O}, 15: 85-25: 75,20 \mathrm{~min}\right)$ at a rate of $4 \mathrm{~mL} / \mathrm{min}$, an injection volume of $200 \mu \mathrm{L}$, and $\mathrm{UV}$ at $254 \mathrm{~nm}$ with column temperature at $30{ }^{\circ} \mathrm{C}$ to obtain compound $6\left(t_{R}=16.25 \mathrm{~min} ; 56.3 \mathrm{mg}\right)$. The subfraction F5-6 was further purified by semi-preparative HPLC $\left(\mathrm{CNCH}_{3} / \mathrm{H}_{2} \mathrm{O}, 25: 75-55: 45,20 \mathrm{~min}\right)$ at a rate of $4 \mathrm{~mL} / \mathrm{min}$, an injection volume of $100 \mu \mathrm{L}$, and $\mathrm{UV}$ at $254 \mathrm{~nm}$ with column temperature at $30{ }^{\circ} \mathrm{C}$ to give $8\left(t_{R}=15.10 \mathrm{~min} ; 5.3 \mathrm{mg}\right)$. Fraction $8(5.63 \mathrm{~g})$ was chromatographed on a silica gel column (100-200 mesh) eluting with a gradient of $\mathrm{CH}_{2} \mathrm{Cl}_{2} / \mathrm{MeOH}(100: 1-1: 1, v / v)$ to afford five subfractions (F8-1 to F8-5). The subfraction F8-2 was separated by Sephadex LH-20 (eluted with 90\% MeOH) and semi-preparative HPLC $\left(\mathrm{CNCH}_{3} / \mathrm{H}_{2} \mathrm{O}, 40: 60-54: 46,20 \mathrm{~min}\right)$ at a rate of $4 \mathrm{~mL} / \mathrm{min}$, an injection volume of $100 \mu \mathrm{L}$, and $\mathrm{UV}$ at $254 \mathrm{~nm}$ with column temperature at $30{ }^{\circ} \mathrm{C}$ to give $3\left(t_{R}=13.35 \mathrm{~min} ; 2.7 \mathrm{mg}\right)$. Fraction $9(2.63 \mathrm{~g})$ was subjected to Sephadex LH-20 with eluted with $90 \% \mathrm{MeOH}$ to give six subfractions (F9-1 to F9-6). Subfraction F9-6 was purified using semi-preparative $\mathrm{HPLC}\left(\mathrm{CNCH}_{3} / \mathrm{H}_{2} \mathrm{O}, 37: 63-80: 20\right.$, $20 \mathrm{~min}$ ) at a rate of $4 \mathrm{~mL} / \mathrm{min}$, an injection volume of $150 \mu \mathrm{L}$, and $\mathrm{UV}$ at $254 \mathrm{~nm}$ with column temperature at $30{ }^{\circ} \mathrm{C}$ to yield $4\left(t_{R}=16.65 \mathrm{~min} ; 8.0 \mathrm{mg}\right)$. Fraction $11(2.03 \mathrm{~g})$ was injected into a Sephadex LH-20 and eluted with $\mathrm{MeOH}$ and further separated by semi-preparative $\mathrm{HPLC}\left(\mathrm{CNCH}_{3} / \mathrm{H}_{2} \mathrm{O}, 43: 57-60: 40,20 \mathrm{~min}\right)$ at a rate of $4 \mathrm{~mL} / \mathrm{min}$, an injection volume of $200 \mu \mathrm{L}$, and $\mathrm{UV}$ at $254 \mathrm{~nm}$ with column temperature at $30{ }^{\circ} \mathrm{C}$ to give $\mathbf{1}\left(\mathrm{t}_{\mathrm{R}}=11.05 \mathrm{~min}\right.$; $23.5 \mathrm{mg}$ ). Fraction 12 (1.62 g) was subjected to Sephadex LH-20 to afford seven subfractions (F12-1 to F12-7). Fraction F12-2 was separated by semi-preparative $\mathrm{HPLC}\left(\mathrm{CNCH}_{3} / \mathrm{H}_{2} \mathrm{O}\right.$, $10: 90-45: 55,25 \mathrm{~min})$, at a rate of $4 \mathrm{~mL} / \mathrm{min}$, an injection volume of $100 \mu \mathrm{L}$, and UV at $254 \mathrm{~nm}$ with column temperature at $30{ }^{\circ} \mathrm{C}$ to afford $10\left(t_{\mathrm{R}}=10.86 \mathrm{~min} ; 5.7 \mathrm{mg}\right)$. Similarly, fraction F12-4 was also separated by semi-preparative $\mathrm{HPLC}\left(\mathrm{CNCH}_{3} / \mathrm{H}_{2} \mathrm{O}, 10: 90-50: 50\right.$, $25 \mathrm{~min}$ ), at a rate of $4 \mathrm{~mL} / \mathrm{min}$, an injection volume of $150 \mu \mathrm{L}$, and UV at $254 \mathrm{~nm}$ with 
column temperature at $30{ }^{\circ} \mathrm{C}$ to obtain $2\left(t_{R}=21.28 \mathrm{~min} ; 7.3 \mathrm{mg}\right)$. Fraction $14(3.60 \mathrm{~g})$ was chromatographed over Sephadex LH-20 eluting with $\mathrm{MeOH}$ and afforded six fractions (F14-1 to F14-6). F14-3 was isolated by semi-preparative HPLC $\left(\mathrm{CNCH}_{3} / \mathrm{H}_{2} \mathrm{O}, 45: 55-77: 23\right.$, $20 \mathrm{~min}$ ) at a rate of $4 \mathrm{~mL} / \mathrm{min}$, an injection volume of $200 \mu \mathrm{L}$, and UV at $254 \mathrm{~nm}$ with column temperature at $30{ }^{\circ} \mathrm{C}$ to give $5\left(t_{R}=17.34 \mathrm{~min} ; 97.8 \mathrm{mg}\right)$. Fr14-4 was separated by semi-preparative $\mathrm{HPLC}\left(\mathrm{CNCH}_{3} / \mathrm{H}_{2} \mathrm{O}, 30: 70-70: 30,20 \mathrm{~min}\right)$ at a rate of $4 \mathrm{~mL} / \mathrm{min}$, an injection volume of $200 \mu \mathrm{L}$, and $\mathrm{UV}$ at $254 \mathrm{~nm}$ with column temperature at $30{ }^{\circ} \mathrm{C}$ to obtain $9\left(t_{R}=11.18 \mathrm{~min} ; 23.6 \mathrm{mg}\right)$. Fr14-6 was further separated by semi-preparative HPLC $\left(\mathrm{CNCH}_{3} / \mathrm{H}_{2} \mathrm{O}, 50: 50-60: 40,20 \mathrm{~min}\right)$ at a rate of $4 \mathrm{~mL} / \mathrm{min}$, an injection volume of $150 \mu \mathrm{L}$, and $\mathrm{UV}$ at $254 \mathrm{~nm}$ with column temperature at $30^{\circ} \mathrm{C}$ to obtain compound $7\left(\mathrm{t}_{\mathrm{R}}=14.44 \mathrm{~min}\right.$; $12.5 \mathrm{mg})$.

\subsubsection{Davidiol E (1)}

$[\alpha]_{\mathrm{D}}^{20}-294.2\left(c\right.$ 0.50, MeOH); UV $(\mathrm{MeOH}) \lambda_{\max }(\log \varepsilon)=230$ (3.40), 310 (3.84) nm; IR $v_{\max }=3327,2953,2843,2115,1647,1450,1111,1016 \mathrm{~cm}^{-1} ; \operatorname{ECD}(c 0.50, \mathrm{MeOH}) \lambda_{\max }(\Delta \varepsilon)=$ 204 (-0.15), 211 (-2.24), 225 (-0.57), 239 (-0.95), $284(+0.64), 320(-1.87)$ nm; For ${ }^{1} \mathrm{H}$ NMR $(600 \mathrm{MHz})$ and ${ }^{13} \mathrm{C}$ NMR $(150 \mathrm{MHz})$ data, see Table 1 ; HRESIMS m/z 541.1861 [M + H] ${ }^{+}$ (calcd. for $\mathrm{C}_{32} \mathrm{H}_{29} \mathrm{O}_{8}$ 541.1857).

\subsubsection{Davidiol F (2)}

$[\alpha]_{\mathrm{D}}^{20}-263.8$ (c 0.50, MeOH); UV (MeOH) $\lambda_{\max }(\log \varepsilon)=210$ (2.22), 305 (1.71) nm; IR $v_{\max }=3414,2951,2841,2129,1647,1450,1112,1016 \mathrm{~cm}^{-1} ; \operatorname{ECD}(c 0.50, \mathrm{MeOH}) \lambda_{\max }(\Delta \varepsilon)=$ $202(+0.25), 212(-5.25), 231(-1.45), 239$ (-1.67), $284(+0.71), 314(-3.27) \mathrm{nm} ;$ For ${ }^{1} \mathrm{H}$ NMR $(600 \mathrm{MHz})$ and ${ }^{13} \mathrm{C}$ NMR $(150 \mathrm{MHz})$ data, see Table 1; HRESIMS m/z $497.1592[\mathrm{M}+\mathrm{H}]^{+}$ (calcd. for $\mathrm{C}_{30} \mathrm{H}_{25} \mathrm{O}_{7} 497.1595$ ).

\subsubsection{Davidinin A (3)}

$[\alpha]_{\mathrm{D}}^{20}-79.8\left(c\right.$ 0.50, MeOH); UV $(\mathrm{MeOH}) \lambda_{\max }(\log \varepsilon)=210(2.18), 285$ (0.60) nm; IR $v_{\max }=3370,2947,2833,1655,1452,1115,1032 \mathrm{~cm}^{-1} ; \operatorname{ECD}(c 0.50, \mathrm{MeOH}) \lambda_{\max }(\Delta \varepsilon)$ $=205$ (+7.52), $214(-4.23), 275(+0.51), 299(-0.20)$ nm; For ${ }^{1} \mathrm{H} \mathrm{NMR}(600 \mathrm{MHz})$ and ${ }^{13} \mathrm{C}$ NMR (150 MHz) data, see Table 2; HRESIMS m/z 409.1282 [M + H] $]^{+}$(calcd. for $\mathrm{C}_{23} \mathrm{H}_{21} \mathrm{O}_{7}$ 409.1282).

\subsubsection{Shandougenine C (4)}

UV $(\mathrm{MeOH}) \lambda_{\max }(\log \varepsilon)=210$ (1.45), $325(1.00) \mathrm{nm} ; \mathrm{IR} \nu_{\max }=3343,2943,2832,1452$, $1032 \mathrm{~cm}^{-1}$; For ${ }^{1} \mathrm{H}$ NMR $(600 \mathrm{MHz})$ and ${ }^{13} \mathrm{C}$ NMR $(150 \mathrm{MHz})$ data, see Table 2; HRESIMS $m / z 575.0949[\mathrm{M}+\mathrm{Na}]^{+}$(calcd. for $\mathrm{C}_{31} \mathrm{H}_{20} \mathrm{NaO}_{10}, 575.0949$ ).

\subsection{ECD Calculations}

The conformational search was performed on Spartan'14 using the MMFF (Merck molecular forcefield) [19]. The conformers with a Boltzmann population of over $1 \%$ were chosen for further optimized by the DFT method at the B3LYP/6-31G(d) level in the gas phase. The calculation of ECD was conducted in MeOH using TDDFT at the B3LYP/6$311+G(d, p)$ level for all conformers of compounds $\mathbf{1}$ and $\mathbf{3}$. All theoretical calculations were performed using the Gaussian 09 program package [20]. The IEF-PCM solvent model for $\mathrm{MeOH}$ was used [21]. The ECD data were processed with SpecDis [22] using $\sigma$ value of $0.3 \mathrm{eV}$ and UV correction of $-3 \mathrm{~nm}$.

\subsection{GLUT-4 Translocation Assay}

Construction of myc-GLUT4-mOrange plasmid and cell line were performed as described previously [23]. Myc-GLUT4-mOrange-L6 cells were cultured on glass coverslips for $12 \mathrm{~h}$, and then L6 myoblasts were differentiated to L6 myotubes. Cells were starved in a PSS solution for $2 \mathrm{~h}$. After starvation, mOrange fluorescence was detected by laserscanning confocal microscopy at an excitation wavelength of $555 \mathrm{~nm}$. Cells were treated 
with $10 \mu \mathrm{g} / \mathrm{mL}$ tested samples and images were taken every $5 \mathrm{~min}$ over a period of $30 \mathrm{~min}$. Zen 2010 Software (Carl Zeiss, Jena, Germany) was used to analyze the fluorescence intensity of mOrange. The detailed method of GLUT-4 fusion with the plasma membrane was described in previous reports [24].

\section{Conclusions}

In this study, two new stilbene oligomers Davidiol E-F (1-2), one new 4-aryl-substituted isoflavan Davidinin A (3), and one new 2-arylbenzofuran dimer, Shandougenine C (4), as well as six known compounds (5-10) were obtained from the roots of Sophora davidii. These compounds presented the effects of stimulated GLUT-4 translocation in L6 cells for 1.282.60 folds, respectively. Specifically, compound 9 exerted the strongest activity for GLUT-4 translocation with 1.60 fold enhancement and compound 6 showed moderate translocation activity with increasing GLUT-4 translocation by 1.39 fold. Our research suggested that compounds 6 and 9 could offer promising lead structures with GLUT-4 translocation activity, which could be meaningful to the development of pharmaceutical products. Meanwhile, it also provided a clue for potentially active anti-diabetic constituents in the plants of genus Sophora.

Supplementary Materials: Supplementary Materials are available online. S1: ECD calculation details; S2-S12: UV, IR, HRESIMS, 1D and 2D NMR spectra and ECD spectrum of compound 1; S13-S23: UV, IR, HRESIMS, 1D and 2D NMR spectra and ECD spectrum of compound 2; S24-S34: UV, IR, HRESIMS, 1D and 2D NMR spectra and ECD spectrum of compound 3; S35-S44: UV, IR, HRESIMS, 1D and 2D NMR spectra of compound 4; S45: The HPLC chromatograms of compounds 1-10; S46: Screening methodology validation.

Author Contributions: Conceived and designed the experiments, K.L., Y.M., X.Y., and H.-Y.C.; the plant material and performed the chemical experiments, Y.M.; in vitro experiment, K.L. and T.Z.; writing of an article, K.L., Y.M., and X.Y. All authors have read and agreed to the published version of the manuscript.

Funding: The work was financially supported by the National Natural Science Foundation of China grants (81911540487, 81573561). We thank Analytical and Measuring Center of School of Pharmaceutical Sciences from South-Central University for Nationalities for testing spectroscopic data.

Data Availability Statement: The data presented in this study are available in Supplementary Material.

Conflicts of Interest: The authors declare no conflict of interest.

Sample Availability: Sample of the compound is available from the authors.

\section{References}

1. Le, Z.; Hu, Q.; Tong, K.; Zhou, C.; Li, J. Epidemiological Characteristics of Diabetes Mellitus in Beilun District of Ningbo, China (2012-2018). J. Diabetes Mell. 2020, 10, 98-107. [CrossRef]

2. Karthikeyan, R.; Marimuthu, G.; Spence, D.W.; Pandi-Perumal, S.R.; BaHammam, A.S.; Brown, G.M.; Cardinali, D.P. Should we listen to our clock to prevent type 2 diabetes mellitus? Diabetes Res. Clin. Pract. 2014, 106, 182-190. [CrossRef] [PubMed]

3. Xu, Q.; Wang, L.; Luo, J.; Shi, D. The Hot and Potential Targets of Type 2 Diabetes Mellitus Treatment in Recent Decade. Curr. Drug Targets. 2018, 19, 55-69. [CrossRef] [PubMed]

4. Leto, D.; Saltiel, A.R. Regulation of glucose transport by insulin: Traffic control of GLUT4. Nat. Rev. Mol. Cell Biol. 2012, 13, 383-396. [CrossRef] [PubMed]

5. $\quad$ Esteves, J.V.; Enguita, F.J.; Machado, U.F. MicroRNAs-Mediated Regulation of Skeletal Muscle GLUT4 Expression an Translocation in Insulin Resistance. J. Diabetes Res. 2017, 2017, 1-11. [CrossRef] [PubMed]

6. Xu, L.; Li, Y.; Dai, Y.; Peng, J. Natural products for the treatment of type 2 diabetes mellitus: Pharmacology and mechanisms. Pharmacoll Res. 2018, 130, 451-465. [CrossRef]

7. Tai, Z.; Cai, L.; Dai, L.; Dong, L.; Wang, M.; Yang, Y.; Cao, Q.; Ding, Z. Antioxidant activity and chemical constituents of edible flower of Sophora viciifolia. Food Chem. 2011, 126, 1648-1654. [CrossRef]

8. Zhao, R.-N. Chinese Herbal Medicine Resources in Gansu Province; Gansu Science and Technology Press: Lanzhou, China, 2004; pp. 773-775.

9. Huang, Y.; Hao, J.; Tian, D.; Wen, Y.; Zhao, P.; Chen, H.; Lv, Y.; Yang, X. Antidiabetic activity of a flavonoid-rich extract from Sophora davidii (Franch.) Skeels in KK-Ay mice via activation of AMP-activated protein kinase. Front Pharmacol. 2018,9 , 760. [CrossRef] 
10. Ma, Y.; Zhou, T.; Zhao, P.; Choi, H.Y.; Hao, J.; Huang, H.; Wu, C.; Yang, X.; Pang, K. New flavonoids from the roots of Sophora davidii (Franch.) Skeels and their glucose transporter 4 translocation activities. Bioorg Chem. 2021, 106, 104500. [CrossRef]

11. Huang, K.-S.; Wang, Y.-H.; Li, R.-L.; Lin, M. Stilbene dimers from the lianas of Gnetum hainanense. Phytochemistry 2000, 54, 875-881. [CrossRef]

12. Li, X.M.; Lin, M.; Wang, Y.H. Stilbenoids from the lianas of Gnetum pendulum. J. Asian Nat. Prod. Res. 2003, 5, 113-119. [CrossRef]

13. Zeng, J.F.; Tan, C.H.; Zhu, D.Y. Manuifolin Q, an unusual 4-aryl-substituted isoflavan from Maackia tenuifolia. J. Asian Nat. Prod. Res. 2004, 6, 45-48. [CrossRef] [PubMed]

14. Luo, G.; Yang, Y.; Zhou, M.; Ye, Q.; Liu, Y.; Gu, J.; Zhang, G.; Luo, Y. Novel 2-arylbenzofuran dimers and polyisoprenylated flavanones from Sophora tonkinensis. Fitoterapia 2014, 99, 21-27. [CrossRef]

15. Liu, Q.; Tu, P. Chemical constituents from Qianliang tea. J. Chin. Pharm. Sci. 2013, 22, 427-430. [CrossRef]

16. Komatsu, M.; Yokoe, I.; Shirataki, Y. Studies on the constituents of sophora species. XIII. Constituents of the aerial parts of Sophora tomentosa L. Chem. Pharm. Bull. 1978, 26, 3863-3870. [CrossRef]

17. Thien, D.D.; Thuy, T.T.; Anh, N.T.H.; Thang, L.Q.; Dai, T.D.; Sa, N.H.; Tam, N.T. A new isoflavanone from Uraria crinita. Nat. Prod. Res. 2019, 7, 1-7. [CrossRef] [PubMed]

18. Yoo, H.S.; Lee, J.S.; Kim, C.Y.; Kim, J. Flavonoids of Crotalaria sessiliflora. Arch. Pharm. Res. 2004, 27, 544-546. [CrossRef] [PubMed]

19. Spartan' 14; Wavefunction Inc.: Irvine, CA, USA, 2013.

20. Frisch, M.J.; Trucks, G.W.; Schlegel, H.B.; Scuseria, G.E.; Robb, M.A.; Cheeseman, J.R.; Scalmani, G.; Barone, V.; Petersson, G.A.; Nakatsuji, H.; et al. Gaussian 09, Revision A. 02; Gaussian, Inc.: Wallingford, CT, USA, 2016.

21. McCann, D.M.; Stephens, P.J.; Cheeseman, J.R. Determination of absolute configuration using density functional theory calculation of optical rotation: Chiral alkanes. J. Org. Chem. 2004, 69, 8709-8717. [CrossRef]

22. Bruhn, T.; Schaumloffel, A.; Hemberger, Y.; Bringmann, G. SpecDis: Quantifying the comparison of calculated and experimental electronic circular dichroism spectra. Chirality 2013, 25, 243-249. [CrossRef]

23. Zhao, P.; Tian, D.; Song, G.; Ming, Q.; Liu, J.; Shen, J.; Liu, Q.H.; Yang, X. Neferine promotes GLUT4 expression and fusion with the plasma membrane to induce glucose uptake in L6 Cells. Front Pharmacol. 2019, 10, 999. [CrossRef]

24. Lv, Y.B.; Ren, W.J.; Zhang, Y.R.; Huang, Y.; Hao, J.; Ma, K.; Ma, Y.R.; Yang, X.Z. Antidiabetic activity of a lipophilic extract from flowers of Wisteria sinensis by targeting the GLUT4 glucose transporter and regulating lipid metabolism disorders. Food Nutr. Res. 2020, 64, 3589. [CrossRef] [PubMed] 